\title{
PENGEMBANGAN MODEL PENGENTASAN KEMISKINAN BERBASIS NILAI-NILAI NYAMABRAYA (Ajaran Tatwamasi) PADA MASYARAKAT PERKOTAAN DI PROVINSI BALI
}

\author{
I Wayan Lasmawan ${ }^{1}$, Made Suryadi ${ }^{2}$ \\ ${ }^{1}$ Jurusan PPKn, Fakultas IImu Sosial, Universitas Pendidikan Ganesha \\ Singaraja, Indonesia \\ 2Jurusan PPKn, Fakultas IImu Sosial, Universitas Pendidikan Ganesha \\ Singaraja, Indonesia \\ e-mail: lasmawanizer@yahoo.com
}

\begin{abstract}
Abstrak
Tujuan jangka panjang penelitian ini adalah: melahirkan sebuah model program penanggulangan kemiskinan yang sesuai dengan aspek lokalitas masyarakat, sehingga mampu menekan laju pertumbuhan tingkat kemiskinan di Indonesia, khususnya di daerah perkotaan. Secara khusus, penelitian ini bertujuan untuk: (1) mengembangkan model pengentasan kemiskinan berbasis nyamabraya, (2) mengembangkan standar operasional prosedur pengentasan kemiskinan berbasis nyamabraya, (3) merumuskan rekomendasi kebijakan public tentang pengentasan kemiskinan berbasis nyamabraya, dan (4) mengembangkan sebuah model rekayasa modalitas social-budaya bagi masyarakat miskin, khususnya untuk daerah perkotaan. Upaya pencapaian (dihasilkannya) model pengentasan kemiskinan berbasis nyamabraya tersebut akan dilakukan melalui serangkaian kegiatan selama 3 (tiga) tahun, dari tahun 2011 sampai dengan tahun 2013 dengan menggunakan paradigma penelitian pengembangan tipe "Prototipycal Studies" yang dipadukan dengan metode "Analisis Reflektif", sehingga akan diperoleh sebuah inovasi terstruktur terkait dengan model pengentasan orang miskin sebagai alternatif-kebijakan dalam peningkatan capaian pembangunan nasional, khususnya di daerah perkotaan.
\end{abstract}

Kata Kunci: Model Pengentasan Kemiskinan, Nyamabraya, Masyarakat Perkotaan

\begin{abstract}
Long-term goal of this research is to produce a model of poverty reduction programs in accordance with aspects of the locality, so as to suppress the growth rate of the poverty level in Indonesia, particularly in urban areas. Specifically, the study aims to: (1) develop a model based "nyamabraya" poverty, (2) develop standard operating procedures based on "nyamabraya" poverty, (3) formulate public policy recommendations on poverty alleviation "nyamabraya" based, and (4) develop a model modalities of social-cultural engineering for the poor, especially for urban areas. Efforts to achieve the (resultant) model-based poverty reduction "nyamabraya" will be done through a series of activities for 3 (three) years, from 2011 to 2013 using the type of development research paradigm "Prototipycal Studies" combined with the "Reflective Analysis", so will obtain a structured innovation associated with the model of poverty reduction as an alternative-policy performance enhancement of national development, particularly in urban areas.
\end{abstract}

Keywords: the model of poverty reduction, Nyamabraya, Urban Areas. 


\section{PENDAHULUAN}

Ditengah hiruk pikuknya "pencitraan public" oleh pemerintah, bahwa tingkat kesejahteraan masyarakat meningkat tajam, yang berarti jumlah masyarakat miskin telah menurun, ternyata fakta dilapangan menunjukkan lain. Di daerah perkotaan, khususnya di Provinsi Bali, ternyata jumlah masyarakat miskin melonjak tajam dari tahun 2009 sebesar 17,2 \% menjadi 28.07 $\%$ pada tahun 2010 (Biro Pusat Statistik Provinsi Bali, 2010). Disisi lain, seiring dengan semakin menajamnya stagnasi ekonomi dan diperkuat oleh desakan inflasi dan dinamika global, telah melahirkan arus urbanisasi yang meningkat setiap tahun. Hal ini tentu melahirkan persoalan baru pada konteks pemberdayaan dan peningkatan kesejahteraan masyarakat, khususnya di perkotaan. Berdasarkan studi pendahuluan yang telah dilakukan, diperoleh kesimpilan bahwa: (1) meningkatnya masyarakat miskin di beberapa kota kabupaten di Bali disebabkan oleh lemahnya kompetensi dan kualifikasi yang dimiliki oleh masyarakat, (2) penduduk miskin yang ada di kota-kota kabupaten di Bali kebanyakan adalah etnis non Hindu Bali, yang dating hanya berbekal "nekat" dan provokasi bali sebagai tujuan pariwisata dunia, dan (3) kelompok masyarakat miskin "sulit keluar" dari garis kemiskinan, karena sistim dan model pengentasan kemiskinan yang dilakukan oleh pemerintah daerah setempat, hanya menyentuh aras permukaan dari akar musabab mereka miskin.

Bertalian dengan fakta empiris dan wacana di atas, maka pelibatan masyarakat sekitar dan dukungan aspek modalitas social-budaya masyarakat sesuai dengan karakteristik daerah setempat adalah sesuatu yang harus dan bersifat mendesak untuk dilakukan. Selama ini, berbagai program pengentasan kemiskinan yang dilakukan, lebih terfokus pada program yang langsung mengarah pada sasaran (masyarakat miskin), namun mengabaikan potensi dan modalitas social masyarakat sekitar, sehingga program tersebut lebih sering gagal dan tidak bertahan lama (berkelanjutan). Bersandar pada fakta ini, maka penelitian ini difokuskan pada upaya penemuan dan pengembangan sebuah model pengentasan kemiskinan yang mengedepankan pada integrasi dan akomodasi modalitas social dan budaya masyarakat setempat, khususnya masyarakat Hindu Bali, yang disebut dengan ajaran "nyamabraya" yaitu sebuah konsep kehidupan bersama dan demokratis tanpa strata yang bersandar pada ajaran "tatwamasi", sehingga benar-benar menyentuh titik persoalan kemanusiaan dalam wujud, isi, dan pelaksanaan program pengentasan kemiskinan, dimana akan terjalin tali temali persaudaraan antar komponen masyarakat untuk secara bersama-sama keluar dari zona kehidupan miskin.

Penelitian Lasmawan (2010) tentang peranan desa adat dalam mengentaskan kemiskinan, menyimpulkan bahwa: (1) kegagalan program pengentasan kemiskinan di beberapa daerah di provinsi bali disebabkan karena minimnya pelibatan desa adat sebagai pemangku kekuasaan tertinggi dalam struktur masyarakat bali, (2) program yang dilaksanakan oleh dinas dan kantor di beberapa kabupaten baru sebatas pemenuhan kebutuhan hidup sesaat masyarakat, sehingga keberlanjutannya sangat kecil bahkan tidak ada, dan (3) terhambatnya pola dan akses komunikasi antara kelompok masyarakat miskin dengan masyarakat daerah setempat, untuk mensinergikan potensi yang dimilikinya, 
sehingga yang miskin semakin miskin dan masyarakat setempat (masyarakat local adat) "cuek" dan tidak peduli. Berangkat dari realitas dan kegagalan program-program pemerintah selama ini dalam mengentaskan kemiskinan sebagaimana beberapa temuan penelitian di atas, khususnya di Provinsi Bali, maka penelitian ini difokuskan pada upaya "pengembangan model program" pengentasan kemiskinan, yang mengedepankan pada integrasi dan elaborasi modalitas social-budaya masyarakat setempat, khususnya ajaran "nyamabraya" yang sangat familiar dikalangan masyarakat Hindu Bali. Hal ini disinyalir mampu meningkatkan dan menguatkan kepemilikan dan tanggungjawab social masyarakat sekitar (masyarakat tidak miskin) untuk secara bersama-sama dan terlibat secara langsung dalam upaya pelaksanaan program pengentasan kemiskinan, sehingga program tersebut lebih produktif dan berhasil secara optimal.

Bersandar pada latar belakang di atas, maka permasalahan pokok dari penelitian ini pada dasarnya adalah: bagaimana model pengentasan kemiskinan yang berbasis nyamabraya, dan bagaimana program tersebut dilaksanakan (standar operasional prosedur), sehingga mampu menjadi dasar bagi pemerintah daerah dalam merumuskan sebuah kebijakan (rekayasa social) public terkait dengan upaya pengentasan kemiskinan, khususnya di daerah perkotaan di Provinsi Bali ?. Ada dua kondisi yang menyebabkan kemiskinan bisa terjadi, yakni: kemiskinan alamiah dan karena buatan. Kemiskinan alamiah terjadi antara lain akibat sumber daya alam yang terbatas, penggunaan teknologi yang rendah dan bencana alam. Kemiskinan "buatan" terjadi karena lembaga-lembaga yang ada di masyarakat membuat sebagian anggota masyarakat tidak mampu menguasai sarana ekonomi dan berbagai fasilitas lain yang tersedia, hingga mereka tetap miskin. Maka itulah sebabnya para pakar ekonomi sering mengkritik kebijakan pembangunan yang melulu terfokus pada pertumbuhan ketimbang pemerataan.

Kemiskinan

merupakan kesenjangan (ketiadaan) akses terhadap unsur kekuasaan sosial (Friedman, 2002 : 67), yang mencakup aspek: (1) ketiadaan tempat tinggal, atau ruang untuk tinggal, termasuk di dalamnya lingkungan fisik di mana keluarga memasak, makan, tidur dan menyimpan benda-benda pribadi ,(2) ketiadaan waktu, jumlah waktu yang tersedia untuk dapat memperoleh kebutuhan subsistensinya, (3) pengetahuan dan ketrampilan, termasuk di dalamnya tingkat pendidikan yang rendah dan pelatihan keterampilan tertentu untuk bekerja, (4). informasi tepat-guna, termasuk di dalamnya informasi mengenai segala aspek kehidupan juga kesempatan ekonomi, seperti metode produksi yang baik, metode sanitasi yang baik, metode pemeliharaan balita, ketersediaan akses terhadap pelayanan umum, dan lain sebagainya, (5). organisasi sosial, baik organisasi formal maupun informal, (6). jaringan sosial, berupa akses untuk melakukan kegiatan kerjasama bagi munculnya tindakan pribadi yang mandiri. Keluarga yang mempunyai akses jaringan kerjasama horisontal yang luas antar sesama keluarga yang lain atau dengan lembaga lain akan mempunyai ruang gerak kegiatan yang lebih luas dibanding dengan yang tidak memilikinya, (7). alat kerja dan kehidupan, tercakup di dalamnya alat produksi bagi keluarga, (8). sumberdaya keuangan, termasuk di dalamnya tingkat pendapatan keluarga dan 
akses terhadap sumber kredit baik formal maupun informal. Kedelapan unsur tersebut merupakan satu-kesatuan yang utuh untuk dapat meningkatkan kekuatan sosial dari keluarga atau masyarakat miskin.

Untuk menanggulangi masalah kemiskinan (program pengentasan kemiskinan) harus dipilih strategi yang dapat memperkuat peran dan posisi perekonomian rakyat dalam perekonomian nasional, sehingga terjadi perubahan struktural yang meliputi pengalokasian sumber daya, penguatan kelembagaan, pemberdayaan sumber daya manusia (Sumodiningrat, 2008). Program yang dipilih harus berpihak dan memberdayakan masyarakat melalui pembangunan ekonomi dan peningkatan perekonomian rakyat. Program ini harus diwujudkan dalam langkah-langkah strategis yang diarahkan secara langsung pada perluasan akses masyarakat miskin kepada sumber daya pembangunan dan menciptakan peluang bagi masyarakat paling bawah untuk berpartisipasi dalam proses pembangunan, sehingga mereka mampu mengatasi kondisi keterbelakangannya. Terdapat tiga pendekatan dalam pemberdayaan masyarakat miskin. Pertama, pendekatan yang terarah, artinya pemberdayaan masyarakat harus terarah yakni berpihak kepada orang miskin. Kedua, pendekatan kelompok, artinya secara bersama-sama untuk memudahkan pemecahan masalah yang dihadapi. Ketiga, pendekatan pendampingan, artinya selama proses pembentukan dan penyelenggaraan kelompok masyarakat miskin perlu didampingi oleh pendamping yang profesional sebagai fasilitator, komunikator, dan dinamisator terhadap kelompok untuk mempercepat tercapainya kemandirian (Soegijoko dkk, 2009:179).
Konsep nyamabraya yang menjadi simpul dasar pertalian antar anggota desa adat di Bali, dapat dijadikan sebagai indicator dan sekaligus komponen utama setiap program pengentasan kemiskinan di Provinsi Bali, sehingga program yang dicanangkan menjadi "hak dan kewajiban komunal" desa adat. Keberadaan dan pelibatan desa adat pada aplikasi ajaran nyamabraya ini, tentu akan memberikan nilai lebih dan sekaligus akan mengakselerasi capaian dari program-program yang dilakukan oleh masing-maisng pemerintah kabupaten atau kota di Provinsi Bali. Nyamabraya merupakan sebuah konsep pokok atau ajaran pokok berkehidupan bagi masyarakat Hindu Bali, yang menekankan pada pertalian komunalitas dan heterogenitas eksklusif. Nyamabraya senantiasa menjadi acuan bagi manusia Hindu Bali dalam melakoni dinamika hidup bermasyarakat. Pokok-pokok ajaran nyamabraya menurut beberapa teks tertulis dan tafsir Weda, terdiri dari: (1) saling ketergantungan antar sesame, penghormatan terhadap perbedaan, (3) perasaaan kepemilikan komunal, (4) kau adalah aku, dan aku adalah kamu, dan (5) tanggungjawab social bersama (Titib, 2009). Dalam aplikasinya, ajaran menyamabraya lebih dimaknai sebagai sebuah pola berkehidupan yang mengedepankan pada kebersamaan atas dasar keterikatan nasib dan tanggungjawan kemanusiaan, sehingga benar-benar terbangun sebuah moralitas social antar sesame anggota masyarakat dalam segala aspek kehidupannya.

Pada konteks peletakan tanggungjawab moral social ini, Lasmawan (2009) menyatakan bahwa, konsep nyamabraya lebih mendekati pemaknaan secara runut akan ajaran tatwamasi yang telah popular dalam masyarakat, khususnya 
masyarakat Hindu Bali. Sementara, Anderson (2006) menekankan pada domain tanggungjawab social dari ajaran nyamabraya, yaitu munculnya hegemoni komunalitas setiap komponen masyarakat dalam penyelesaian berbagai persoalan atau konflik yang disandarkan pada kepentingan masyarakat secara bersama, yaitu hidup yang mapan secara social dan ekonomi. Konsep nyamabraya pada tataran kehidupan masyarakat modern lebih dimaknai sebagai sebuah pola berkehidupan yang bersinergi melalui integrasi potensi antar anggota masyarakat untuk keluar dari sebuah persoalan, termasuk mengenai kemiskinan yang bersifat regional. Pada kasus local, konsep nyamabraya ini selalu menjadi inti dari setiap gerakan masyarakat desa adat untuk menjaga dan mempertahankan integritas dan keagungan desa adat sebagai simbolisme masyarakat Hindu Bali. Bertalian dengan generalisasi ini, maka bilamana konsep nyamabraya ini diletakkan dan dilekatkan pada program pengentasan masyarakat miskin, maka akan menjadi motor dan sekaligus inti dari program tersebut, sehingga secara langsung akan berpengaruh terhadap keberlanjutan dan keberhasilan program itu sendiri.

Bersandar pada latar belakang dan kajian pustaka di atas, maka tujuan pokok dari penelitian ini pada dasarnya adalah: mengembangkan model pengentasan kemiskinan yang berbasis nyamabraya, yang dilengkapi dengan bagaimana program tersebut dilaksanakan (standar operasional prosedur), sehingga mampu menjadi dasar bagi pemerintah daerah dalam merumuskan sebuah kebijakan (rekayasa social) public terkait dengan upaya pengentasan kemiskinan, khususnya di daerah perkotaan. Produk akhir dari penelitian ini adalah: model pengentasan kemiskinan berbasis nyamabraya, standar operasional prosedur (SOP) pengentasan kemiskinan berbasis nyamabraya, model rekayasa sosial berbasis nyamabraya, dan rekomendasi kebijakan pengentasan kemiskinan berbasis nyamabraya. Produk penelitian ini sangat bermanfaat bagi upaya percepatan dan penemuan formula baru bagi pengentasan masyarakat miskin, khususnya di daerah perkotaan yang merupakan program pembangunan nasional.

\section{METODE PENELITIAN}

Fokus utama dari penelitian ini adalah mengembangkan model pengentasan kemiskinan berbasis nyamabraya, standar operasional prosedur pengentasan kemiskinan berbasis nyamabraya, model rekayasa sosial berbasis nyamabraya, dan rekomendasi kebijakan pengentasan kemiskinan berbasis nyamabraya. Berdasarkan rasional tersebut, maka penelitian ini menggunakan desain penelitian pengembangan tipe "Prototipycal Studies" sebagaimana yang dikedepankan oleh Akker (1999) dan Plomp (2001). Hal penting yang perlu diperhatikan dalam penelitian pengembangan adalah kualitas perangkat pembelajaran (produk) yang dihasilkan. Plomp (2001), memberikan kriteria kualitas produk yaitu: valid (merefleksikan pengetahuan state-of-the-art dan konsistensi internal), mempunyai nilai tambah (added value), praktis, dan efektif. Secara umum, Plomp (2001), menyatakan bahwa pelaksanaan penelitian pengembangan meliputi tiga fase yaitu: fase analisis hulu-hilir (front-end analysis), fase pengembangan prototipe (prototyping phase), dan fase penilaian (assessment phase) atau evaluasi sumatif. Bertalian dengan fokus masalah penelitian ini yaitu 


\begin{abstract}
mengembangkan model program pengentasan kemiskinan berbasis nyamabraya, standar operasional prosedur pengentasan kemiskinan berbasis nyamabraya, model rekayasa sosial berbasis nyamabraya, dan rekomendasi kebijakan pengentasan kemiskinan berbasis nyamabraya, sampai dihasilkannya model program pengentasan kemiskinan berbasis nyamabraya yang benar-benar valid, praktis, dan efektif.
\end{abstract}

\section{HASIL PENELITIAN}

\section{Profil Masyarakat Miskin Perkotaan di Provinsi Bali}

Berdasarkan hasil studi

dokumentasi, wawancara, dan penyebaran kuisioner terhadap responden yang tersebar di 8 kabupaten dan 1 kota madya di Privinsi Bali, maka dapat disimpulkan bahwa: terjadinya kemiskinan perkotaan di Bali lebih banyak distimuli oleh ketimpangan potensi diri masyarakat dengan sebaran lapangan pekerjaan yang tersedia di masyarakat. Berdasarkan data yang diperoleh, maka terdapat beberapa faktor dominan pemicu munculnya masyarakat miskin di daerah perkotaan Bali, yaitu: (1) ketidakmampuan bersaing memperoleh pekerjaan, (2) sempitnya lapangan kerja yang tersedia di lingkungan tempat tinggalnya, (3) arus urbanisasi yang berlebih pada masyarakat bali, (4) penduduk pendatang dari luar bali dengan modalitas "nekat", (5) budaya miskin "lokal masyarakat" tertentu, (6) ketimpangan kebijakan pembangunan, khususnya di daerah urban, (7) "sabotase sumber daya" oleh pemodal/investor, dan (8) pembagian kue pariwisata yang tidak menyentuh "aras dalam" kehidupan masyarakat, dimana hampir semua kabupaten/kota memiliki potensi pariwisata di Provinsi Bali.
Dilihat dari asal daerahnya, maka hampir $52.7 \%$ masyarakat miskin perkotaan di provinsi Bali adalah masyarakat pendatang dari luar bali, sedangkan masyarakat pendatang dari provinsi bali adalah $41.2 \%$, dan hanya $6.01 \%$ yang merupakan penduduk asli daerah itu sendiri. Artinya, secara komunal, masyarakat perkotaan di Bali bukanlah pemicu utama munculnya kemiskinan di daerah perkotaan. Sementara dilihat dari area atau lokasi tempat tinggal masyarakat miskin itu sendiri, dapat disimpulkan bahwa sebagian besar (78.3\%) tinggal di daerah pinggiran kota, dan hanya $21.7 \%$ yang tinggal di beberapa kantong (gang sempit atau perkampungan) di tengah-tengah kota. Dilihat dari jenjang pendidikan pada kalangan masyarakat miskin perkotaan, maka dari data statistik yang diperoleh pada 8 kabupaten (badung, bangli, gianyar, kelungkung, buleleng, karangasem, tabanan, dan negara) dan 1 kota madya (denpasar), dapat disimpulkan bahwa (pembulatan) : $61 \%$ mereka berpendidikan sekolah dasar dan/atau tidak selesai, $19 \%$ berpendidikan SMP sederajat, $12 \%$ berpendidikan SMA sederajat, $8 \%$ berpendidikan diploma/sarjana. Sementara dilihat dari asal daerahnya, sebagian besar masyarakat miskin perkotaan di Bali adalah masyarakat Bali yang melakukan urbanisasi ke beberapa kota, dengan meninggalkan desa asalnya, kemudian asal jawa timur, berikutnya NTB, dan dari daerah lainnya di pulau Jawa dan NTT. Sementara untuk Bali, paling banyak pendatang yang tergolong masyarakat miskin di kota-kota di provinsi bali dapat dirinci sebagai berikut: karangasem, buleleng, bangli, negara, tabanan, kelungkung, badung, gianyar dan denpasar. 


\section{Modalitas Sosial - Budaya Masyarakat Bali Dalam Penanganan Kemiskinan}

Secara struktural-phenomenon, masyarakat Hindu Bali memiliki beberapa potensi lokal yang sangat menonjol dalam kaitannya dengan pengembangan dan integrasi nilai-nilai lokal dalam pengentasan masyarakat miskin perkotaan. Berdasarkan hasil wawancara, studi dokumentasi, dan penyebaran kuisioner, diperoleh potret kekuatan dan kelemhan modalitas sosial dan budaya masyarakat Bali dalam kaitannya dengan pengembangan model pengentasan masyarakat miskin perkotaan berbasis nyama braya, yaitu: (1) desa Adat, (2) sekehe (perkumpulan sosial-budaya), (3) lembaga ketahanan desa, (4) konsep nyama braya, (5) ajaran tatwamasi, (6) sumber daya alam yang subur dan mereta di setiap region, (7) adanya modalitas stimulus dari pemerintah maupun lembaga perkreditan desa, (8) konstruk budaya bali yang berbasis kekeluargaan, dan (9) adanya keyakinan (belief) masyarakat bali akan kesejahteraan abadi dari sang pencipta.

\section{Program dan Harapan Penanganan Kemiskinan Perkotaan di Bali}

Adat, budaya dan agama di Bali adalah satu-kesatuan yang tak bisa dipisahkan. Maka, membangun adat adalah juga meningkatkan nilai budaya dan agama (pendapat dan pendirian sebagian responden). Melestarikan budaya adalah juga melestarikan adat dan agama. Sehingga pemimpin Bali seharusnya selalu berpijak pada landasan agama, adat dan budaya, baik dalam menelurkan kebijakan maupun dalam menyelenggarakan pembangunan. Artinya seorang pemimpin harus bersikap dan berlaksana sesuai tatwa dan susila. Kepala BPS Bali, Suryamin, menyatakan dalam wawancara yang dilakukan tim peneliti, bahwa ada sejumlah faktor yang mempengaruhi pengurangan penduduk miskin sepanjang Maret 20112012. "Pertama, kenaikan upah harian buruh tani dan buruh bangunan selama triwulan I-2011 dan triwulan I- 2012 yakni masing-masing 2,96 persen dan 4,81 persen," ungkap kala ditemui di kantornya, Jakarta, Senin (2/7/2012). Lalu kedua, penerima beras murah atau raskin dalam tiga bulan terakhir pada kelompok 20 persen penduduk dengan pendapatan terendah meningkat dari 13,30 persen pada 2011 menjadi 17,21 persen pada 2012 di wilayah perkotaan. Di pedesaan juga terjadi kenaikan 13,3 persen menjadi 17,2 persen dalam kurun waktu yang sama. Ketiga, penerima pelayanan kesehatan gratis selama enam bulan terakhir pada 20 persen penduduk dengan pendapatan terendah meningkat dari 2011 ke 2012 yakni 4,6 persen menjadi 5,6 persen di perkotaan. Sementara di pedesaan, penerima pelayanan kesehatan gratis juga naik menjadi 4,7 persen pada tahun ini. Faktor keempat, adalah adanya perbaikan penghasilan petani yang ditunjukkan oleh Nilai Tukar Petani sebesar 1,32 persen menjadi 104,68 pada Maret 2012. Faktor kelima, tumbuhnya perekonomian Indonesia sebesar 6,3 persen pada triwulan I-2012 dari triwulan yang sama tahun sebelumnya. Sedangkan pengeluaran konsumsi rumah tangga tumbuh 4,9 persen pada periode yang sama. Terakhir, dari sisi ukuran subyektif, persentase rumah tangga di kuantil terbawah yakni 20 persen penduduk dengan pendapatan terendah, yang menyatakan bahwa penghasilannya cukup untuk memenuhi kebutuhan sehari-hati dalam sebulan terakhir meningkat menjadi 12,4 persen pada 2012 di wilayah perkotaan. 
Berdasarkan observasi dan analisis dokumen, dapat dikatakan bahwa penanganan masalah kemiskinan nampaknya tidak sesuai dengan situasi dan kondisi dimasyarakat. Dimana seharusnya dalam program-program pengentasan kemiskinan semestinya memerlukan pendekatan tersendiri sesuai dengan situasi/kondisi budaya yang dianut dimasing-masing daerah.Seperti halnya pada masyarakat Bali yang menganut sistem kekerabatan patrilineal tentunya berbeda penanganannya dengan masyarakat yang menganut budaya matrilineal. Masalah ketimpangan dan atau ketidak adilan gender merupakan fenomena penting di kalangan masyarakat perkotaan di Bali. Fakta ini dapat diperkuat oleh temuan lapangan, yang menunjukkan bahwa: masih tampaknya dan diakuinya oleh masyarakat tentang kemiringan perlakuan dan akses dalam bidang bidang pendidikan, ketenagakerjaan, dan aktivitas politik.Angka buta huruf perempuan nyatanya lebih tinggi dibandingkan dengan laki-laki.Para perempuan cenderung bekerja disektor domestik bahkan termasuk pekerja keluarga tanpa bayaran (lebih dari $70 \%$ ) dari pada publik dan berpenghasilan lebih rendah. Demikian juga bidang politik umumnya didominasi oleh laki-laki. Responden perempuan mengatakan bahwa gender atau analisis gender berkaitan dengan masalah yang sangat dalam dikehidupan bersama manusia karena bukan hanya mempertanyakan sistem dan struktur-struktur yang telah mapan mengenai kedudukan wanita dan pria didalam masyarakat, tetapi juga mempertanyakan hubungan kekuasaan.Dengan kata lain masalah gender atau analisis gender membuka hakhak istimewa yang dinikmati oleh sekelompok manusis (pria) sebagai hak-hak istimewa mengenai kedudukan khususnya pria di dalam kehidupan bersama mereka.

\section{Modalitas Penanganan Kemiskinan Berbasis Nyamabraya dalam Konstruk Hindu}

Berdasarkan observasi, studi dokumen, dan penyebaran kuisioner diperoleh fakta bahwa: desa di Bali terutama didasarkan atas kesatuan tempat. Sebagian dari tanah wilayahnya adalah milik para warga desa sebagai individu, tetapi sebagian lagi adalah tanah yang ada di bawah hak pengawasan desa, atau secara konkret dibawah pengawasan pimpinan desa yang sering disebut "Karang Desa". Desa-desa di pegunungan biasanya mempunyai pola - pola perkampungan yang memusat, sedangkan desa-desa yang mempunyai sistem banjar dan desa-desa di daerah dataran, mempunyai pola yang terpencar. Di samping kesatuan wilayah maka sebuah desa merupakan pula suatu kesatuan keagamaan yang di tentuakan oleh suatu kompleks kuil desa yang disebut kayangan tiga ialah Pura Puseh, Pura Bale Agung dan Pura Dalem. Ada kalanya Pura Puseh dan Pure Bale Agung dijadikan satu dan disebut Pura Desa. Seperti telah diterangkan sebelumnya, konsep mengenai arah adalah amat penting artinya dalam agama orang Bali. Dalam kehidupan kemasyarakatan desa di Bali, ada organisasi-organisasi yang bergerak dalam lapangan kehidupan yang khusus, ialah sekaha. Organisasi ini bersifat turuntemurun, tapi ada pula yang bersifat sementara. Ada sekaha yang fungsinya adalah menyelenggarakan hal-hal atau upacara-upacara yang berkenan dengan desa, misalnya sekaha baris (perkumpulan tari baris), sekaha teruna-teruni, sekehe 
gong (kumpulan para pemain alat musik/gong). Sekaha tersebut sifatnya permanen, tapi ada juga sekaha yang sifatnya sementara, yaitu sekaha yang didirikan berdasarkan atas suatu kebutuhan tertentu, misalnya sekaha memula (perkumpulan menanam), sekaha manyi (perkumpulan menuai), sekaha gong (perkumpulan gamelan) dan lain-lain. Berdasarkan kajian dokumen dan fakta lapangan, Masyarakat Bali yang tradisional dan penghidupannya yang bersifat agraris tampak sebagai satu kesatuan yang utuh, kepentingan bersama lebih diutamakan dibandingkan kepentingan kelompok dan individu sebagai warga masyarakat. Warga masyarakat satu dengan yang lainnya terikat berdasarkan ikatan solidaritas mekanis dan dalam masyarakat demikian, dunia kehidupan masih menyatu. Berdasarkan kajian lapangan, dan menjaring harapan masyarakat miskin perkotaan, ma dapat disimpulkan empat upaya prioritas yang mesti dikembangkan untuk meningkatkan taraf hidup masyarakat miskin perkotaan di Bali, yaitu: Pertama, memperkuat posisi tawar dan memeperkecil ketergantungan masyarakat miskin dari kelas sosial di atasnya dengan cara memperbesar kemungkinan mereka melakukan diversifikasi usaha. Kedua, memberikan bantuan permodalan kepada masyarakat miskin dengan bunga yang rendah dan berkelanjutan. Ketiga, memberi kesempatan kepada masyarakat miskin untuk dapat ikut terlibat menikmati hasil keuntungan dari produknya dengan cara menetapkan harga yang adil. Keempat, mengembangkan kemampuan masyarakat miskin agar memiliki ketrampilan dan keahlian untuk memberi nilai tambah pada produk dan hasil usahanya. Upaya pengentasan kemiskinan yang dianjurkan menurut kebijaksanaan pemberdayaan masyarakat, tidak lain adalah kebijaksanaan yang memberi ruang gerak, fasilitas publik dan menciptakan kesempatan-kesempatan yang kondusif bagi maraknya kemampuan dan kemungkinan kelompok masyarakat miskin untuk mengatasi masalah mereka sendiri dan tidak menekan serta mendesak mereka ke pingir-pinggir atau ke posisi ketergantungan. Adalah menjadi tanggung jawab semua pihak dengan komitmen politik yang tinggi memberikan dukungan yang kuat terhadap upaya pemberdayaan masyarakat untuk mengantar dan mendukung kaum perempuan berjuang secara mandiri, demokratis, dan berbudaya.

\section{Prototype Model Pengentasan Kemiskinan Perkotaan di Provinsi Bali}

Berdasarkan hasil wawancara dan penyebaran kuisioner kepada responden, diperoleh data bahwa, keengganan perempuan dalam rumah tangga miskin untuk ikut secara aktif terlibat dalam kegiatan - kegiatan yang diselenggarakan organisasai PKK juga merupakan faktor penghambat peran aktif perempuan dalam mengentaskan kemiskinan. Mereka juga lebih memilih pekerjaan yang dapat dilakukan di rumah tanpa harus meninggalkan keluarga. Keberpihakan bantuan/upaya-upaya yang dilakukan pemerintah dalam pengentasan kemiskinan terhadap perempuan dalam rumah tangga miskin dapat dipaparkan sebagai berikut, dalam hal ini pemerintah menyalurkan bantuan yang disebut dengan SPP ( Simpan Pinjam Perempuan ) bantuan ini berupa bantuan pemberian modal yang disalurkan melalui tanggung jawab kelompok dasa wisma. Melalui organisasi PKK ditingkat Kabupaten , pemerintah menyelenggarakan pelatihan-pelatihan keterampilan yang 
tujuannya untuk meningkatkan keterampilan ibu-ibu sehingga nantinya dapat dikembangkan untuk menciptakan peluang usaha, seperti pelatihan mengolah hasil pertanian, membuat kue dan lain-lain. Salah satu upaya yang dapat dilakukan untuk meningkatkan standar kehidupan masyarakat miskin di Provinsi Bali adalah melalui pemberdayaan. Pemberdaya-an pada dasarnya merupakan suatu proses yang dijalankan dengan kesadaran dan partisipasi penuh dari pihak terkait untuk meningkatkan kapasitas dan kapabilitas masyarakat sebagai sumberdaya pembangunan agar mampu mengenali permasalahan yang dihadapi dalam mengembangkan dan menolong dirinya menuju keadaan yang lebih baik, mampu menggali dan memanfaatkan sumberdaya yang tersedia untuk kepentingan diri dan kelompoknya, serta mampu mengeksistensikan diri secara jelas dengan mendapat manfaat darinya. Pemberdayaan adalah sebuah "proses menjadi", bukan "proses instan". Sebagai suatu proses, pemberdayaan mempunyai tiga tahapan yaitu penyadaran, pengkapasitasan, dan pendayaan. Tahap pertama adalah penyadaran. Masyarakat miskin diberikan pemahaman bahwa mereka mempunyai hak untuk eksis.

\section{PEMBAHASAN}

Beranjak dari beberapa hal dalam uraian diatas dapat dinyatakan bahwa : 1) Heterogenitas masyarakat Bali tak dapat dihindari dan sudah terjadi serta akan terus terjadi dan semakin hari semakin kompleks. 2) Setiap komunitas masyarakat memang memiliki kearifan lokal, demikian pula masyarakat Bali dengan kearifan lokalnya yang mengandung nilai persaudaraan dapat dijadikan pedoman dalam menjalin kerukunan hidup bersama dari masyarakat yang beragama (multikultural) dan berbeda (agama, etnis, adat-istiadat, ras, dan golongan). 3) di dalam setiap agama ada ajaran yang senada dengan nilai kearifan lokal dan setiap agama memberi semangat agar umatnya bisa rukun secara intern maupun ekstern. 4) atas dasar pemahanman tentang kearifan lokal Bali dan kerukunan yang ada kesepadanannya dalam agama masing-masing yang dikaji lewat dialog antarumat beragama di Bali secara berkesinambungan, maka kerukunan hidup beragama dan bermasyarakat di Bali selama ini tergolong baik, walaupun kondisi rukunnya lebih baik pada tataran atas sementara pada tataran bawah masih perlu pembinaan secara merata dan terus menerus. Upaya ke depan adalah agar kerukunan yang sudah dicapai bisa dijaga, dipelihara, dan ditingkatkan dengan lebih mendalami ajaran agama masing-masing dan nilai-nilai kearifan lokal yang dapat dijadikan dasar untuk hidup bersama saling berdampingan secara damai dan harmonis dan dapat saling menerima, saling menghargai dan saling menghormati perbedaan. Tranformasi nilai harus terjadi secara alami dari satu generasi ke generasi berikutnya dan selalu diharapkan adanya perubahan yang mengarah kepada kondisi yang lebih baik dari sebelumnya. Politik identitas erat kaitannya dengan perubahan sosial. Teori-teori utama berkenaan dengan politik identitas dikembangkan oleh beberapa pakar/teoritikus, seperti Chris Barker dalam Cultural Studies: Teori dan Praktik (2000). Teorinya menyebutkan bahwa identitas diri bertalian dengan konsepsi yang kita yakini tentang diri kita, sementara harapan dan pendapat orang lain membentuk identitas sosial. Keduanya berbentuk narasi atau menyerupai cerita. 
Jadi identitas sepenuhnya adalah konstruksi sosial dan tidak mungkin eksis di luar representasi budaya dan akulturasi. Berger dan Luckmann (1990) mempertegas konsepsi tersebut dengan menyebutkan bahwa, identitas lahir melalui proses sosialisasi dan identifikasi yang terusmenerus. Oleh karenanya, identitas sudah dirancang dengan sangat seksama, dalam arti dapat mencerminkan sepenuhnya kenyataan obyektif di mana identitas itu berada. Singkatnya, setiap orang 'adalah' benar-benar apa yang diandaikan tentang dia. Dalam masyarakat seperti itu, setiap identitas mudah dikenal secara obyektif maupun subyektif. Upaya mengentaskan kemiskinan selayaknya sesegera mungkin harus dilakukan, terlebih lagi pada perempuan dalam rumah tangga miskin karena kaum perempuan mempunyai potensi yang tinggi dalam upaya mengentaskan kemiskinan. Terlebih lagi perempuan Bali dikenal termasuk pekerja keras dengan etos kerja yang tinggi,tidak mudah berpangku tangan,tekun dan ulet bekerja guna mensejahterakan kehidupan rumah tangganya. Perempuan Bali sebagai pekerja keras mendapatkan penanganan yang tepat tentunya merupakan salah satu modal dalam menanggulagi kemiskinan, untuk itulah penelitian ini penting dilakukan.

Hasil temuan menunjukkan bahwa profil perempuan dalam rumah tangga miskin secara sosial perempuan dalam rumah tangga miskin tidak tersingkir dari institusi utama masyarakat yang ada karena data empiris menunjukkan perempuan dalam rumah tangga miskin sebagian besar terlibat dalam lingkungan desa adat, masih bisa ikut terlibat dalam kegiatan adat/agama (menyame braya), walaupun tidak banyak /tidak aktif terlibat dalam organisasi PKK.

\section{KESIMPULAN}

Berdasarkan temuan penelitian dan pembahasan hasil sebagaimana yang telah disajikan pada bab-bab sebelumnya, maka dapat ditarik dan diformulasikan simpulan sebagai berikut: (1) masyarakat miskin perkotaan di provinsi bali pada umumnya adalah masyarakat pendatang (74,3 \%), sementara sisanya adalah masyarakat urban yang berasal dari kabupaten lain di wilayah Bali. (2) model program pengentasan kemiskinan yang relevan dikembangkan di kalangan masyarakat miskin perkotaan bali adalah dengan mengoiptimalkan modalitas sosial dan budaya dasar masyarakat bali, yaitu konsep nyamabraya, agar tali temali simpul kebersamaan semakin erat diantara penghuni kawasan di tanah bali. (3) standar operasional prosedur yang mesti dikembangkan harus mengacu pada peletakan desa adat sebagai inti dari semua garis komando dan koordinasi penanganan kemiskinan, karena desa adat merupakan simbolisme adat dan budaya masyarakat bali. (4) rekomendasi yang relevan bagi para pemangku dan pengambil kebijakan dalam kaitannya dengan pengentasan kemiskinan di Bali, adalah dengan mengoptimalkan lembaga-lembaga sosial dan budaya masyarakat setempat, sehingga menjadi urat nadi bagi semua program yang digagas dan dilaksanakan oleh pemerintah daerah setempat. (5) model rekayasa sosial pengentasan kemiskinan perkotaan di bali terdiri dari sub-sub sistem dengan prototype sebagai berikut: konsep nyamabraya, integritas potensi, kesadaran komunal, perasaan senasib, tanggungjawan sosial bersama, kebersamaan secara ekonomis, pengawasan terkoordinasi, keberlanjutan dalam kebersamaan, dan tujuan bersama. 
Secara diagramatik dapat dijabarkan sebagai berikut:

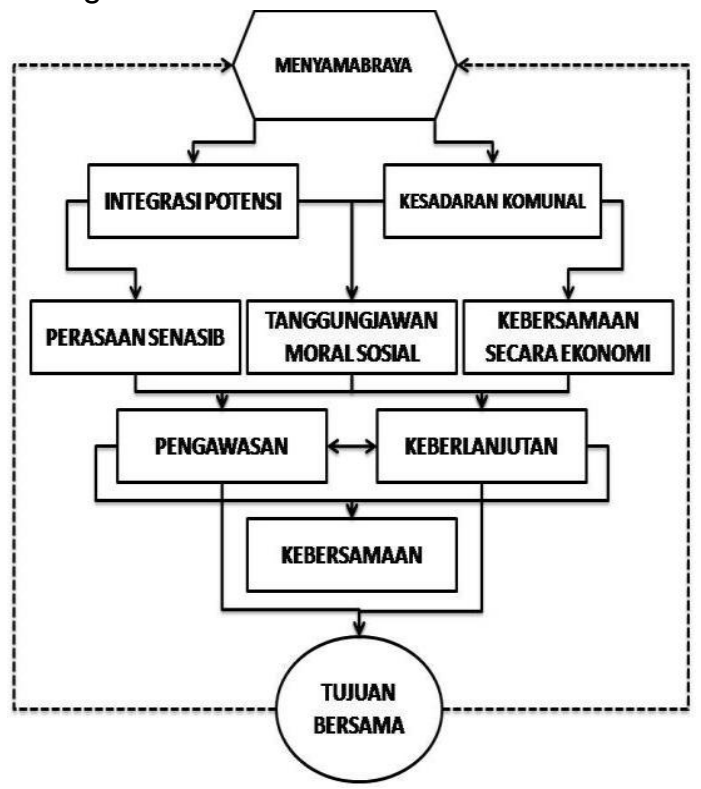

\section{DAFTAR PUSTAKA}

Badir, Akhmadi. (2009). Dilematisasi Penanganan Masyarakat Miskin di Daerah Perkotaan: Analisis Kebijakan Publik. Jurnal PP. Volume 121, Tahun ke-2, (21-29)

Badan Perencanaan Pembangunan Nasional dan Departemen Dalam Negeri, Pedoman Program Inpres Desa Tertinggal, Jakarta, 1993.

Badan Pusat Statistik, Penduduk Indonesia: Hasil Sensus Penduduk 2008 (Seri: RBL 1.1), Jakarta 2008, dan tahuntahun sebelumnya.

Badan Pusat Statistik, Profil Penduduk Indonesia Tahun 2009 (atau SP sebelumnya), Jakarta, 2009.

Badan Pusat Statistik, Data dan Informasi Kemiskinan Tahun 2009, Jakarta, 2009.

Badan Pusat Statistik, Statistik Indonesia 2009, Jakarta 2009.

Bali dalam Angka. (2009). Penjabaran
Biro Pusat Statistik, Kemiskinan dan Pemerataan Pendapatan di Indonesia 1991 - 2000, Jakarta, 2001. (24)

Buddelmeyer, Hielke and Emmanuel Shoufias, 2008, "An Evaluation of the Performance of Regression Discountinuity Design on PROGRESA," Policy Research Working Paper 3386, World Bank, Washington DC.

Burtless, Gary,2005, "Are Targeted Wage Subsidies Harmful? Evidence from a Wage Voucher Experiment," Industrial and Labor Relations Review, Vol. 39, pp. 105-115.

Foster, James, J. Greer, and Erik Thorbecke, 2004, "A Class of Decomposable Poverty Measures," Econometrica , 52: 761-765

Hart, Keith, "Informal Income Opportunities and Urban Employment in Ghana" dalam lan Livingston (ed), Development Economies and Policy: Readings, George Allen \& Unwin Ltd, London, 2001.

Inten, Gede. (2008). Pemetaan Masalah Sosial dan Ekonomi Masyarakat Miskin di Kota Buleleng - Bali. Laporan Penelitian. Singaraja: Lembaga Penelitian Undiksha.

Kementerian Koordinasi Bidang Kesejahteraan Rakyat (Tim Koordinasi Penyiapan Penyusunan Perumusan Kebijakan Penanggulangan Kemiskinan), Dokumen Interim Strategi Penanggulangan Kemiskinan, Jakarta, 2004.

Lasmawan, Wayan. (2006). Major Driven Kemiskinan Masyarakat Bali: Antara Idealisme Agama dan Idealisme Sosial. Laporan Penelitian. Denpasar. Bappeda Provinsi Bali.

Lasmawan, Wayan. (2008). Analisis Kebijakan Pengentasan Kemiskinan 
Masyarakat Kota Dilihat dari efektivitas Program dan Partisipasi Masyarakat Sekitar. Laporan Penelitian. Denpasar: Bappeda Kabupaten Badung.

Remi, Subyatie Soemitro dan Priyono Tjiptoherijanto, Kemiskinan dan Kemerataan di Indonesia, Penerbit Reneka Cipta, Jakarta, 2002.

Suryadi, Made. (2007). Studi evaluative Kebermanfaatan Lembaga Sosial dan Lembaga Karang Taruna dalam Program Percepatan Pengentasan Kemiskinan di Kabupaten Buleleng Bali. Laporan Penelitian. Singaraja: Dinas Sosial Kabupaten Buleleng.

Suryadi, Made. (2008). Studi analisis factorfaktor pendorong kemiskinan perkotaan (studi kasus pada masyarakat kota Singaraja - Bali). Laporan Penelitian. Singaraja: Lembaga Penelitian Undiksha.

Todaro, Michael P., Pembangunan Ekonomi di Dunia Ketiga (Terjemahan) Jilid I, Penerbit Erlangga, Jakarta, 2000.

World Bank (Urban Sector Development Unit, Infrastructure Development, East Asia and Pacific Region), Kota-kota Dalam Transisi: Tinjauan Sektor Perkotaan Pada Era Desentralisasi di Indonesia (terjemahan), Dissemination Paper No 7, June 30, 2003. 